\title{
Methods for the Direct Isolation and Enumeration of Actinophages in Soil
}

\author{
By SHIRLEY LANNING AND S. T. WILLIAMS* \\ Department of Botany, P.O. Box 147, University of Liverpool, Liverpool L69 3BX, U.K.
}

(Received 13 October 1981; revised 3 February 1982)

\begin{abstract}
Existing direct isolation methods may seriously underestimate the actual numbers of actinophages in soil, since major 'losses' may be incurred during agitation, filter sterilization and, to a lesser extent, centrifugation. Two methods were devised for the isolation and enumeration of soil actinophages and were compared experimentally with two previously described methods. Numbers of up to $2 \times 10^{4}$ p.f.u. (g soil) $)^{-1}$ were detected in compost soil.
\end{abstract}

\section{INTRODUCTION}

Phages for many bacterial genera may be readily isolated from most soils by enrichment of the soil with the potential host (Adams, 1959; Billing, 1969; Willoughby et al., 1972; Dowding, 1973; Dowding \& Hopwood, 1973; Zachary, 1974), with nutrients (Reanney \& Marsh, 1973; Casida \& Liu, 1974; Tan \& Reanney, 1976; Germida \& Casida, 1981) or with both host and nutrients (Newbould \& Garrard, 1954; Retinskaya \& Rautenstein, 1960). Phages thus isolated have been widely used in biochemical, genetic and taxonomic research. Ecological studies, however, may require knowledge of the numbers of phages present in natural, unamended systems. Reanney \& Marsh (1973) have suggested that if phages occurred in soil at $0 \cdot 1 \%$ of the titre obtained under optimum laboratory conditions, they must be the most numerous genetic objects in that habitat. Phages are, therefore, potentially agents of prime ecological importance.

Methods for the direct isolation of phages from soil usually yield extremely low titres (Khavina, 1954; Welsch et al., 1955; Reanney, 1968; Collard, 1970; Casida \& Liu, 1974; Tan \& Reanney, 1976). Problems associated with direct isolation include: (i) inactivity of the hosts (Gray \& Williams, 1971), hence the increases in phage numbers on enrichment; (ii) inactivation or loss of phages due to the use of inappropriate eluent, extraction and sterilization techniques; (iii) the inability of direct assays to detect phages in close physical association with resting cells (Casida \& Liu, 1974) or adsorbed to soil colloids (Robinson \& Corke, 1959; Sykes \& Williams, 1978).

In the investigation reported here, some of the factors influencing the efficiency of direct isolation of actinophages from soil were assessed. New approaches were outlined for obtaining a more realistic estimate of the numbers of actinophages in soil.

\section{METHODS}

Actinomycetes and actinophages. Spore suspensions of the following streptomycetes in $10 \%(\mathrm{v} / \mathrm{v})$ glycerol were prepared and stored at $-18^{\circ} \mathrm{C}$ (Wellington \& Williams, 1978). Streptomyces lavendulae (International Streptomyces Project 069), S. michiganensis (ISP 015), S. griseus (ISP 236), Streptomyces sp. (Mx 1), Streptomyces sp. (Mx 2), Streptomyces sp. (Mx 3). Pure stocks of actinophages $\phi 069$ and $\phi \mathrm{Mx} 2$ were inoculated together with their hosts, $S$. lavendulae (ISP 069) and Streptomyces sp. (Mx 2) on plates of nutrient agar (NA) (Oxoid CM3), pH 7.0 and incubated at $25^{\circ} \mathrm{C}$ for $16 \mathrm{~h}$. Areas of confluent lysis were transferred to vials containing nutrient broth (NB) (Oxoid CM69), pH 7.0, shaken at 800 oscillations per minute (o.p.m.) on a reciprocal flask shaker (Griffin and George Ltd) for $15 \mathrm{~min}$ and allowed to stand at $4^{\circ} \mathrm{C}$ for $16 \mathrm{~h}$. The resulting phage suspensions (approximately $10^{7}$ p.f.u. $\mathrm{ml}^{-1}$ ) were filter-sterilized (Millipore type HAWP, pore size $0.45 \mu \mathrm{m}$ ).

Soils. Fresh soils were sieved through a $2 \mathrm{~mm}$ mesh and stored in polythene bags at $4{ }^{\circ} \mathrm{C}$. Sub-samples of sieved sand, arable and garden (1) soils (Table 1) were air-dried for $4 \mathrm{~d}$ and stored in polyethylene screw-capped bottles. The $\mathrm{pH}$ of soil samples was determined in water extracts using a soil : water ratio of $1: 2$ with a glass electrode and a 
direct-reading pH meter. Water content was determined by loss in weight of soil samples dried to constant weight at $55^{\circ} \mathrm{C}$. Percentage organic matter was measured by loss in weight on ignition at $850^{\circ} \mathrm{C}$ for $30 \mathrm{~min}$ (Ball, 1964). Particle size distribution was determined by a modification of the hydrometer method (Day, 1965). Soils were sterilized by autoclaving at 15 p.s.i. (103.5 kPa) for $20 \mathrm{~min}$.

Actinophage assay. This was carried out by a modification of the double-layer method (Adams, 1959). Actinophage suspension or sterile soil extract suitably diluted in NB $(1 \mathrm{ml})$ was inoculated on to a basal layer of NA. NB $(2.5 \mathrm{ml})$ containing $0.6 \%(\mathrm{w} / \mathrm{v})$ agar (Oxoid L13), maintained at $45^{\circ} \mathrm{C}$, was inoculated with a spore suspension of the streptomycete host and poured over the basal layer. Five replicate plates were prepared and incubated at $25^{\circ} \mathrm{C}$ for $16 \mathrm{~h}$ when plaques were counted.

Factors affecting the recovery of actinophages added to sterile soil. Some factors which might influence the recovery of added actinophages from sterile soil were studied. These included agitation procedure and extraction period, eluent, centrifugation and filter sterilization.

The basic method was as follows. Stock actinophage $\phi 069$ suspension was added to $20 \mathrm{~g}$ of sterile, air-dried sand in $100 \mathrm{ml}$ flasks to give a concentration of approximately $10^{2}$ p.f.u. (g sand) $)^{-1}$. Eluent $(50 \mathrm{ml}$ ) was added and extracts agitated, then allowed to stand at $25^{\circ} \mathrm{C}$ for $30 \mathrm{~min}$. The supernatants were centrifuged at $1200 \mathrm{~g}$ for 30 $\mathrm{min}$, filter-sterilized, and the filtrate assayed for actinophage $\phi 069$. This method was progressively modified according to the results of the following sections.

(i) Agitation procedure and extraction period. Sand extracts in NB ( $\mathrm{pH} 7 \cdot 0)$ were agitated for 15,30 and 60 min at $4{ }^{\circ} \mathrm{C}$ using an orbital incubator (Gallenkamp) at $200 \mathrm{rev} . \mathrm{min}^{-1}$, a magnetic stirrer (Biotec, Solna, Sweden) at 300 rev. $\mathrm{min}^{-1}$ and a reciprocal flask shaker at 200 o.p.m. Supernatants were centrifuged and assayed for actinophage $\phi 069$ without filtration.

(ii) Eluent. The following eluents were assessed: NB, pH 7.0;3\%(w/v) beef extract (BE) (Oxoid L29), $\mathrm{pH} 7 \cdot 0$; 1.0 M-glycine buffer (Sigma 600-5), pH 8.7; 1.0 M-sodium nitrate (BDH 10255); peptone/yeast/calcium broth (PYCa) (Bradley et al., 1961), pH 7.0; glucose/Casamino acid/proline broth (GCP) (Sykes, 1977), pH 7.0. The effects of $\mathrm{pH}$ and the protein content of the eluent on actinophage recovery were also tested by adjusting the $\mathrm{pH}$ of NB with $0.1 \mathrm{M}-\mathrm{NaOH}$ to between 7.0 and $10 \cdot 0$. Bovine albumin (Sigma, A4503), gelatin (Oxoid L8) or egg albumen (Difco 0147-5-7) were added to NB, pH 8.0 at concentrations of up to $1000 \mathrm{mg} \mathrm{l}^{-1}$.

Extracts were shaken on the reciprocal flask shaker for $30 \mathrm{~min}$ at $4^{\circ} \mathrm{C}$ at 200 o.p.m., centrifuged, filter-sterilized and the filtrate assayed for actinophage $\phi 069$.

(iii) Filter sterilization. The titres of a suspension of actinophage $\phi 069$ in NB were compared before and after filtration. The filters compared were Gelman (type GA-6, cellulose triacetate, pore size $0.45 \mu \mathrm{m}$; Gelman Hawksley, Lancing, Sussex) and Millipore (type HAWP, mixed cellulose acetate and nitrate, pore size $0.45 \mu \mathrm{m}$ ). Pretreatments of the Millipore filter were compared. Filters were soaked for $4 \mathrm{~h}$ in $2 \%(\mathrm{v} / \mathrm{v})$ Decon 90 (Decon Laboratories, Brighton, Sussex), $0 \cdot 1 \%(\mathrm{v} / \mathrm{v})$ Tween $80(\mathrm{BDH} 56023), 2 \%(\mathrm{w} / \mathrm{v})$ gelatin, $3 \%(\mathrm{w} / \mathrm{v}) \mathrm{BE}(\mathrm{pH} 8 \cdot 0), \mathrm{NB}$ (pH 8.0) and NB with $0 \cdot 1 \%(\mathrm{w} / \mathrm{v})$ egg albumen (pH 8.0).

The effect of filtration of soil extracts on recovery of actinophage $\phi 069$ from sterile sand was also tested. Sand was shaken as before with $50 \mathrm{ml} \mathrm{NB}$ plus $0 \cdot 1 \%(\mathrm{w} / \mathrm{v})$ egg albumen (pH 8.0). Extracts were centrifuged and the supernatant assayed for actinophage $\phi 069$ either directly or after filtration through untreated Millipore filters or filters pretreated with $0.1 \%(\mathrm{v} / \mathrm{v})$ Tween $80,2 \%(\mathrm{w} / \mathrm{v})$ gelatin, $3 \%(\mathrm{w} / \mathrm{v}) \mathrm{BE}(\mathrm{pH} 8.0)$ or $\mathrm{NB}(\mathrm{pH} 8.0)$.

(iv) Centrifugation. Soil extracts were shaken as before and allowed to stand at $4{ }^{\circ} \mathrm{C}$ for $16 \mathrm{~h}$, when half the supernatant was centrifuged at $1200 \mathrm{~g}$ for $30 \mathrm{~min}$. The supernatants from centrifuged and uncentrifuged samples were assayed for actinophage $\phi 069$ without filtration.

Comparison of four procedures for the isolation and enumeration of actinophages in soils. The efficiencies of the following isolation methods were evaluated by comparison of recoveries of added actinophage $\phi \mathbf{M x} 2$ from sterile sand, arable and garden (1) soils. Actinophage $\phi \mathrm{Mx} 2$ suspension was added to sterile soils in $100 \mathrm{ml}$ flasks to give a final concentration of $116.5 \times 10^{2}$ p.f.u. (g soil) $)^{-1}$.

Method $A$ (Welsch et al., 1955). Sterile distilled water $(60 \mathrm{ml})$ was added to each flask which was then shaken frequently during a period of 2 to $3 \mathrm{~h}$. Soil suspensions were filtered (Whatman no. 1) and sterilized by filtration (Millipore type HAWP, pore size $0.45 \mu \mathrm{m}$ ). Seitz filters originally used in this method were unobtainable. The filtrates were assayed for actinophage $\phi \mathbf{M x} 2$.

Method B (Sykes, 1977). Sterile NB (60 ml, pH 7.0) was added to each flask, which was then shaken on an orbital incubator at $200 \mathrm{rev} . \mathrm{min}^{-1} 25^{\circ} \mathrm{C}$ for $60 \mathrm{~min}$. Soil suspensions were allowed to stand at $25^{\circ} \mathrm{C}$ for $30 \mathrm{~min}$. The supernatants were centrifuged at $1200 \mathrm{~g}$ for $15 \mathrm{~min}$, sterilized by filtration (Millipore type HAWP, pore size $0.45 \mu \mathrm{m})$ and assayed for actinophage $\phi \mathrm{Mx} 2$.

Method $C$ (Devised procedure for chloroform-sensitive actinophage). NB $(50 \mathrm{ml})$ containing $0 \cdot 1 \%(\mathrm{w} / \mathrm{v}) \mathrm{egg}$ albumen $(\mathrm{pH} \mathrm{8.0)}$ was added to each flask. Soil extracts were shaken on a reciprocal flask shaker at 200 o.p.m. for $30 \mathrm{~min}$ at $4{ }^{\circ} \mathrm{C}$ and allowed to stand at $4{ }^{\circ} \mathrm{C}$ for $16 \mathrm{~h}$. The supernatants were centrifuged at $1200 \mathrm{~g}$ for $30 \mathrm{~min}$, sterilized by filtration (Millipore type HAWP, pore size $0.45 \mu \mathrm{m}$ ) and assayed for actinophage $\phi \mathrm{Mx} 2$.

Method D (Devised procedure for chloroform-tolerant actinophage). The basic procedures were as for chloroformsensitive actinophage. However, after centrifugation, $5 \mathrm{ml}$ of the supernatant was transferred to a sterile vial and 
Table 1. Properties of soils used

\begin{tabular}{|c|c|c|c|c|c|c|c|}
\hline \multirow[b]{2}{*}{ Soil } & \multirow[b]{2}{*}{$\mathrm{pH}$} & \multirow{2}{*}{$\begin{array}{c}\text { Water } \\
\text { content } \\
\text { (\% fresh } \\
\text { weight) }\end{array}$} & \multirow{2}{*}{$\begin{array}{l}\text { Loss-on- } \\
\text { ignition } \\
\text { (\% air-dry } \\
\text { weight) }\end{array}$} & \multicolumn{4}{|c|}{$\begin{array}{l}\text { Particle size distribution } \\
\text { (\% oven-dry weight) }\end{array}$} \\
\hline & & & & $\begin{array}{c}\text { Coarse } \\
\text { sand }\end{array}$ & $\begin{array}{l}\text { Fine } \\
\text { sand }\end{array}$ & Silt & Clay \\
\hline Sand & $8 \cdot 6$ & 1.8 & $3 \cdot 0$ & $65 \cdot 5$ & $34 \cdot 5$ & 0 & 0 \\
\hline Compost & $7 \cdot 6$ & $44 \cdot 4$ & $19 \cdot 3$ & $39 \cdot 1$ & 51.9 & $9 \cdot 0$ & 0 \\
\hline Arable & 6.9 & $26 \cdot 0$ & $10 \cdot 2$ & $44 \cdot 3$ & $42 \cdot 1$ & $10 \cdot 7$ & $2 \cdot 9$ \\
\hline Garden (1) & $7 \cdot 7$ & 29.7 & $14 \cdot 1$ & $37 \cdot 4$ & $43 \cdot 8$ & $10 \cdot 9$ & $7 \cdot 9$ \\
\hline Garden (2) & $7 \cdot 1$ & $12 \cdot 3$ & $6 \cdot 9$ & 54.9 & $36 \cdot 5$ & 1.0 & $7 \cdot 6$ \\
\hline Garden (3) & $7 \cdot 5$ & $25 \cdot 2$ & $10 \cdot 8$ & $63 \cdot 6$ & $30 \cdot 4$ & $3 \cdot 7$ & $2 \cdot 3$ \\
\hline Garden (4) & $8 \cdot 2$ & $19 \cdot 4$ & $11 \cdot 1$ & $34 \cdot 3$ & $49 \cdot 7$ & $10 \cdot 6$ & $5 \cdot 4$ \\
\hline Cultivated (1) & $7 \cdot 5$ & $15 \cdot 4$ & $6 \cdot 2$ & $43 \cdot 5$ & $46 \cdot 6$ & $8 \cdot 3$ & 1.6 \\
\hline Cultivated (2) & $7 \cdot 6$ & $22 \cdot 0$ & $6 \cdot 7$ & $47 \cdot 0$ & $46 \cdot 9$ & $6 \cdot 1$ & 0 \\
\hline
\end{tabular}

0.1 ml chloroform added (Crosse \& Hingorani, 1958). Vials were shaken on a reciprocal flask shaker at 200 o.p.m. for $5 \mathrm{~min}$ and allowed to stand at $4{ }^{\circ} \mathrm{C}$ for $2 \mathrm{~min}$. The aqueous layer was assayed for actinophage $\phi \mathrm{Mx} 2$.

The four methods described above were used to isolate and enumerate indigenous actinophage for six Streptomyces spp. in eight fresh soils (Table 1).

\section{RESULTS AND DISCUSSION}

\section{Factors influencing the recovery of actinophages from soil}

Agitation. Maximum recovery (117\%) of actinophage $\phi 069$ added to sand was obtained when $\mathrm{NB}$ extracts were shaken at 200 o.p.m. on a Griffin reciprocal flask shaker for $30 \mathrm{~min}$ at $4{ }^{\circ} \mathrm{C}$ (Table 2). Fifty-eight percent were recovered from unshaken extracts, 43 and $4 \%$ after orbital shaking and magnetic stirring, respectively. Losses in the shaken samples may have been due to surface inactivation at the air/water interface, or to adsorption to the glass surface of the flasks, which occurs with bacteriophages and animal viruses (Troubworst et al., 1974). Inactivation of certain physiologically active proteins such as enzymes and toxins by shaking is well known (Adams, 1948).

Eluent. NB containing $0 \cdot 1 \%(\mathrm{w} / \mathrm{v})$ egg albumen at $\mathrm{pH} 8.0$ was selected as the optimum eluent. Greater numbers of phages were recovered from sand extracted with complex media such as $\mathrm{NB}, \mathrm{GCP}$ and PyCa broth than with deionized water, glycine buffer or $\mathrm{NaNO}_{3}$ (Table 3). Most bacterial viruses are stable when diluted in broth, serum, ascitic fluid and similar diluents, but all are less stable and some totally unstable when diluted in salt solutions or chemically defined media (Adams, 1948).

Maximum recovery $(70 \%)$ of actinophage $\phi 069$ was obtained when NB was adjusted to $\mathrm{pH}$ $8 \cdot 0$ (Table 3 ). Isolation of actinophages from soils has previously been shown to depend on the $\mathrm{pH}$ of the eluent (Khavina \& Rautenstein, 1959). Actinophages were rarely isolated when the $\mathrm{pH}$ of the eluting medium was $<7 \cdot 0$. Similarly, elution of Arthrobacter phages added to loam was most efficient when the eluent (deionized water or beef extract/glucose broth) was adjusted to pH 7.8 to 8.2 (Ostle \& Holt, 1979). Adsorption of virus on to biological and non-biological surfaces depends largely on the ionic composition and $\mathrm{pH}$ of the medium in which they are suspended (Bitton, 1975; Duboise et al., 1976). The use of an eluent with high pH might therefore be expected to increase desorption of negatively charged phage particles from the cation-exchange sites in soils. The stability of actinophages, however, is generally sensitive to pH values greater than 9.0 (Sykes et al., 1981), thus the extremely high pH values used to isolate poliovirus and enterovirus (Landry et al., 1978; Hurst et al., 1978; Hurst \& Gerba, 1979) were not appropriate.

The addition of bovine albumin or gelatin to NB pH 8.0 had little effect on actinophage recoveries (Table 4). The addition of $0.1 \%(\mathrm{w} / \mathrm{v})$ egg albumen, however, significantly increased the recovery of actinophage $\phi 069$ from 43 to $83 \%(P<0.05)$ probably by reducing inactivation during shaking and promoting desorption of phage particles from clay minerals. The adsorption 
Table 2. Effect of agitation method and extraction period on the recovery of actinophage $\phi 069$ from sterile sand

The number of phage added was $30.5 \times 10^{2}$ (g air-dried sand $)^{-1}$. Tukey's L.S.D.0.05 $($ Winer, 1962) $=$ 5.42 . The numbers in parentheses indicate the percentage of added phage recovered.

\begin{tabular}{|c|c|c|c|c|}
\hline \multirow[b]{2}{*}{ Method } & \multirow[b]{2}{*}{ Time } & \multicolumn{3}{|c|}{$\begin{array}{l}\text { No. of phage recovered } \\
{\left[10^{-2} \times \text { p.f.u. }(\mathrm{g} \text { air-dried sand })^{-1}\right]}\end{array}$} \\
\hline & & $10 \mathrm{~min}$ & $30 \mathrm{~min}$ & $60 \mathrm{~min}$ \\
\hline Unshaken & & $16 \cdot 7(55)$ & $17 \cdot 7(58)$ & $17 \cdot 3(57)$ \\
\hline Orbital incubator, $200 \mathrm{rev} . \mathrm{min}^{-1}$ & & $17 \cdot 0(56)$ & $13 \cdot 0(43)$ & $9 \cdot 0(29)$ \\
\hline Magnetic stirrer, $300 \mathrm{rev} . \mathrm{min}^{-1}$ & & $5 \cdot 7(19)$ & $1 \cdot 3(4)$ & $0 \quad(0)$ \\
\hline Reciprocal flask shaker, 200 o.p.m & & $21 \cdot 7(71)$ & $35 \cdot 7(117)$ & $22 \cdot 3(73)$ \\
\hline
\end{tabular}

Table 3. Effect of different eluents on the recovery of actinophage $\phi 069$ from sterile sand The number of phage added was $171.0 \times 10^{3}$ (g air-dried sand) ${ }^{-1}$. Tukey's L.S.D.0.05 (Winer, 1962) $=$ 12.44.

\begin{tabular}{|c|c|c|}
\hline Eluent & $\begin{array}{l}\text { No. of phage recovered } \\
{\left[10^{-2} \times \text { p.f.u. (g air- }\right.} \\
\left.\text { dried sand })^{-1}\right]\end{array}$ & $\begin{array}{c}\text { Percentage of added } \\
\text { phage recovered }\end{array}$ \\
\hline Deionized water & $56 \cdot 3$ & 33 \\
\hline GCP broth & $97 \cdot 3$ & 57 \\
\hline $1.0 \mathrm{M}$-glycine buffer, $\mathrm{pH} 8.7$ & $86 \cdot 7$ & 51 \\
\hline $\mathrm{BE}(3 \%, \mathrm{w} / \mathrm{v})$ & $75 \cdot 3$ & 44 \\
\hline PYCa broth & $93 \cdot 0$ & 54 \\
\hline $1.0 \mathrm{M}-\mathrm{NaNO}_{3}$ & 0.7 & 0.4 \\
\hline NB, pH 7.0 & $106 \cdot 0$ & 62 \\
\hline $\mathrm{NB}, \mathrm{pH} 8.0$ & $120 \cdot 0$ & 70 \\
\hline $\mathrm{NB}, \mathrm{pH} 9.0$ & $101 \cdot 0$ & 59 \\
\hline $\mathrm{NB}, \mathrm{pH} 10 \cdot 0$ & $14 \cdot 3$ & 8 \\
\hline
\end{tabular}

Table 4. Effect of addition of protein to the eluent $(N B, p H 8.0)$ on the recovery of actinophage $\phi 069$ from sterile sand

The number of phage added was $247.0 \times 10^{2}$ (g air-dried sand $)^{-1}$. Tukey's L.S.D.0.05 (Winer, 1962) $=$ $15 \cdot 42$.

No. of phage recovered

Protein additive $\left[10^{-2} \times\right.$ p.f.u. (g air- Percentage of added

$\left(\mathrm{mg}^{-1}\right) \quad$ dried sand $)^{-1}$ ] phage recovered

Bovine albumin

$\begin{array}{rrr}0 & 137 \cdot 3 & 55 \\ 10 & 122 \cdot 0 & 49 \\ 100 & 166 \cdot 3 & 67 \\ 1000 & 163 \cdot 0 & 66\end{array}$

Gelatin

$\begin{array}{rrr}0 & 136 \cdot 7 & 55 \\ 10 & 144 \cdot 7 & 58 \\ 100 & 137 \cdot 7 & 56 \\ 1000 & 127.0 & 51\end{array}$

Egg albumen

$\begin{array}{rrr}0 & 107 \cdot 0 & 43 \\ 10 & 132 \cdot 7 & 54 \\ 100 & 168 \cdot 0 & 68 \\ 1000 & 205 \cdot 0 & 83\end{array}$


Table 5. Effect of filtration on the titre of a suspension of actinophage $\phi 069$

Tukey's L.S.D.0.05 $($ Winer, 1962) $=17 \cdot 52$.

\begin{tabular}{|c|c|c|c|}
\hline & & Phage titre & Percentage of unfiltered \\
\hline Filter type & Pretreatment & $\left(10^{-2} \times\right.$ p.f.u. $\left.\mathrm{ml}^{-1}\right)$ & phage titre \\
\hline None & None & $302 \cdot 3$ & \\
\hline Gelman* & None & $135 \cdot 7$ & 45 \\
\hline Millipore $†$ & None & $219 \cdot 7$ & 73 \\
\hline Millipore & 'Decon 90 ' $(2.0 \%, \mathrm{w} / \mathrm{v})$ & $21 \cdot 7$ & 7 \\
\hline Millipore & Gelatin $(2.0 \%, \mathrm{w} / \mathrm{v})$ & $195 \cdot 7$ & 65 \\
\hline Millipore & BE $(3.0 \%, w / v)$ pH 8.0 & $154 \cdot 0$ & 51 \\
\hline Millipore & $\mathrm{NB}, \mathrm{pH} 8 \cdot 0$ & $165 \cdot 0$ & 55 \\
\hline Millipore & $\begin{array}{l}\mathrm{NB}+\text { egg albumen } \\
(0 \cdot 1 \%, \mathrm{w} / \mathrm{v}) \mathrm{pH} 8 \cdot 0\end{array}$ & $124 \cdot 3$ & 41 \\
\hline Millipore & 'Tween $80^{\prime}(0.1 \%, w / v)$ & $161 \cdot 0$ & 53 \\
\hline
\end{tabular}

* Gelman (type GA-6, cellulose triacetate, pore size $0.45 \mu \mathrm{m}$ )

$\dagger$ Millipore (type HAWP, mixed cellulose acetate and nitrate, pore size $0.45 \mu \mathrm{m}$ ).

Table 6. Effect of filtration on the recovery of actinophage $\phi 069$ from sterile sand

The number of phage added was $280.3 \times 10^{2}$ (g air-dried sand $)^{-1}$. Tukey's L.S.D.0.05 $($ Winer, 1962) $=$ $36 \cdot 95$.

$\begin{array}{lcc}\begin{array}{c}\text { Pre-treatment of } \\ \text { Millipore filters }\end{array} & \begin{array}{c}\text { No. of phage recovered } \\ {\left[10^{-2} \times \text { p.f.u. }(g \text { air- }\right.} \\ \left.\text { dried sand })^{-1}\right]\end{array} & \begin{array}{c}\text { Percentage of added } \\ \text { phage recovered }\end{array} \\ \text { No filter } & 259 \cdot 0 & 92 \\ \text { None } & 122 \cdot 3 & 44 \\ \text { Gelatin }(2 \cdot 0 \%, \mathrm{w} / \mathrm{v}) & 92 \cdot 3 & 33 \\ \text { BE }(3 \cdot 0 \%, \mathrm{w} / \mathrm{v}) \mathrm{pH} 8 \cdot 0 & 119 \cdot 0 & 42 \\ \text { NB, pH } 8 \cdot 0 & 127 \cdot 0 & 45 \\ \text { 'Tween } 80 \text { ' }(0 \cdot 1 \%, \mathrm{w} / \mathrm{v}) & 124 \cdot 0 & 44\end{array}$

of virus to clay minerals may be reduced or prevented by the presence of proteinaceous materials such as egg albumen and bovine albumin (Carlson et al., 1968; Burge \& Enkiri, 1978; Ostle \& Holt, 1979), foetal bovine serum (Jakubowski, 1969) or foetal calf serum (Gerba et al., 1977; Ramia \& Sattar, 1979). The surface inactivation of virus and phage on shaking may also be reduced by the addition of small amounts of protein to the medium (Adams, 1948; Troubworst et al., 1974).

Filter sterilization. Filtration of a suspension of actinophage $\phi 069$ resulted in losses of 55 and $27 \%$ of the original titre with Gelman cellulose triacetate (type GA-6) and Millipore cellulose acetate and nitrate (type HAWP) filters, respectively (Table 5). Pretreatment of filters with proteins such as gelatin, BE and NB or surface-active agents such as Tween 80 and Decon 90 , reduced the number of actinophage $\phi 069$ in the filtrate. De Vicente (1959) also found considerable differences in the degree of adsorption of phages to different filter types. Ninety-two percent of actinophage $\phi 069$ added to sterile sand were recovered from an unfiltered extract in NB plus $0.1 \%(\mathrm{w} / \mathrm{v})$ egg albumen, pH 8.0 (Table 6$)$. Filtration of the extract with untreated filters or filters pretreated with selected protein solutions or surface-active agents gave significantly reduced recoveries ( 33 to $45 \%$ ) of added actinophage $\phi 069$. Collard (1970) showed that membrane filtration of a soil extract in water resulted in a $90 \%$ reduction and Seitz filtration, a $99 \%$ reduction in numbers of actinophages detected. Willoughby et al. (1972) also observed a considerable loss of Actinoplanes phage activity when host-enriched soil suspensions were filtered.

Centrifugation. Centrifugation of soil extracts at $1200 \mathrm{~g}$ for $15 \mathrm{~min}$ resulted in small reductions $(P \leqslant 0.05)$ in the numbers of added actinophage $\phi 069$ recovered from sterile arable and garden soils (Table 7). Centrifugation had no effect on the number of actinophage $\phi 069$ recovered from 
Table 7. Effect of centrifugation on the recovery of actinophage $\phi 069$ from sterile soils

The number of phage added was $150.0 \times 10^{2}$ (g air-dried soil $)^{-1}$. Tukey's L.S.D.0.05 $($ Winer, 1962) $=$ $12 \cdot 72$.

\begin{tabular}{|c|c|c|c|}
\hline Soil & $\begin{array}{l}\text { Centrifugation of } \\
\text { soil suspension }\end{array}$ & $\begin{array}{c}\text { No. of phage recovered } \\
{\left[10^{-2} \times \text { p.f.u. (g air- }\right.} \\
\left.\text { dried soil })^{-1}\right]\end{array}$ & $\begin{array}{c}\text { Percentage of added } \\
\text { phage recovered }\end{array}$ \\
\hline Sand & $\begin{array}{l}\text { None } \\
1200 \mathrm{~g}, 15 \mathrm{~min}\end{array}$ & $\begin{array}{l}146 \cdot 0 \\
142 \cdot 3\end{array}$ & $\begin{array}{l}97 \\
95\end{array}$ \\
\hline Arable & $\begin{array}{l}\text { None } \\
1200 \mathrm{~g}, 15 \mathrm{~min}\end{array}$ & $\begin{array}{l}140 \cdot 0 \\
124 \cdot 3\end{array}$ & $\begin{array}{l}93 \\
83\end{array}$ \\
\hline Garden (1) & $\begin{array}{l}\text { None } \\
1200 \mathrm{~g}, 15 \mathrm{~min}\end{array}$ & $\begin{array}{l}139 \cdot 7 \\
119 \cdot 0\end{array}$ & $\begin{array}{l}93 \\
79\end{array}$ \\
\hline
\end{tabular}

Table 8. Comparison of the efficiency of four isolation methods by the recovery of actinophage $\phi M X 2$ added to sterile soils

\begin{tabular}{|c|c|c|c|c|}
\hline & \multicolumn{4}{|c|}{$\begin{array}{l}\text { No. of phage recovered } \\
{\left[10^{-2} \times \text { p.f.u. }(\mathrm{g} \text { air-dried soil })^{-1}\right]}\end{array}$} \\
\hline Soil & Method A & Method B & Method C & Method D \\
\hline $\begin{array}{l}\text { Sand } \\
\text { Arable } \\
\text { Garden (1) }\end{array}$ & $\begin{array}{l}21.0(18) \\
15.9(13) \\
37.5(32)\end{array}$ & $\begin{array}{l}29 \cdot 5(25) \\
21 \cdot 3(18) \\
35 \cdot 1(30)\end{array}$ & $\begin{array}{r}101 \cdot 7(87) \\
85 \cdot 8(74) \\
39.9(34)\end{array}$ & $\begin{array}{l}111 \cdot 2(96) \\
108 \cdot 7(93) \\
138 \cdot 3(118)\end{array}$ \\
\hline
\end{tabular}

sterile sand. This is consistent with sand having fewer adsorption sites than clay soils (Bitton, 1975; Burge \& Enkiri, 1978).

Comparison of four methods for the isolation and enumeration of actinophages in soils

Between 96 and $100 \%$ of added actinophage $\phi \mathrm{Mx} 2$ were recovered from the three test soils using Method D (Table 8). This method was the most efficient. Method $\mathrm{C}$ was generally more efficient than Methods A and B $(P \leqslant 0 \cdot 05)$. Eighty-seven and $74 \%$ of added actinophage $\phi \mathrm{Mx} 2$ were recovered from sand and arable soils, respectively, but only $34 \%$ from the garden soil. The latter contained the highest proportion of clay and any method involving filtration will thus result in low phage recovery due to the adsorption to the filter of the phage/colloid complexes. The recovery efficiencies of Methods A and B were extremely low (13 to 32\%) for all soils.

The four methods may be ranked in terms of their efficiency for the direct isolation and enumeration of actinophages for six streptomycetes in eight soils as follows: Method D > Method C > Method B > Method A (Table 9). The greatest number of actinophages were obtained from the compost soil. Method D yielded approximately thirty times the number of actinophages obtained by Method A and three times that obtained by Methods B and C (Streptomyces sp. Mx 3). Similar results were obtained for arable soil (Streptomyces $\mathrm{sp} . \mathrm{Mx} 2, \mathbf{M x}$ 3, ISP 236) and garden (1) soil (Streptomyces sp. Mx 1, Mx 3).

In some soils there was no significant difference in the numbers of actinophages obtained by Methods C and D, e.g. arable (Streptomyces sp. Mx 1), garden (2) (Streptomyces sp. Mx 1, Mx 2, Mx 3, ISP 236) and cultivated (1) (Streptomyces sp. ISP 069). Assuming that approximately $50 \%$ of actinophages may be retained by the filter (Method C) there could have been a high proportion of chloroform-sensitive actinophages for the given host in these soil populations. Alternatively, there may have been a large proportion of small actinophages which can pass readily through the filter. Actinophages for Streptomyces michiganensis (ISP 015) were isolated from cultivated (2) soil by Methods B and C, but not by Method D. This suggests that all members of the actinophage population for $S$. michiganensis (ISP 015) in this soil were chloroform-sensitive.

Streptomycete hosts Mx 1, Mx 2 and Mx 3 were isolated from compost, arable and garden 
Table 9. Comparison of four methods for the direct isolation and enumeration of actinophages in natural soils

\begin{tabular}{|c|c|c|c|c|c|}
\hline \multirow[b]{3}{*}{ Soil } & \multirow{3}{*}{$\begin{array}{l}\text { Streptomycete } \\
\text { host }\end{array}$} & \multicolumn{4}{|c|}{$\begin{array}{l}\text { No. of phage recovered } \\
\text { [p.f.u. }(\mathrm{g} \text { soil })^{-1} \text { ] }\end{array}$} \\
\hline & & \multicolumn{4}{|c|}{ Method*: } \\
\hline & & A & B & $\mathrm{C}$ & D \\
\hline Compost & $\begin{array}{l}\text { Mx } 1 \\
\text { Mx } 2 \\
\text { Mx } 3 \\
\text { ISP } 069 \\
\text { ISP } 015 \\
\text { ISP } 236\end{array}$ & $\begin{array}{c}514 \cdot 5 \\
669 \cdot 0 \\
785 \cdot 0 \\
0 \\
0 \\
87 \cdot 0\end{array}$ & $\begin{array}{c}2173 \cdot 0 \\
5820 \cdot 0 \\
6885 \cdot 0 \\
0 \\
0 \\
566 \cdot 0\end{array}$ & $\begin{array}{c}2916 \cdot 7 \\
3916 \cdot 7 \\
7262 \cdot 5 \\
0 \\
0 \\
397 \cdot 3\end{array}$ & $\begin{array}{c}12387 \cdot 3 \\
12008 \cdot 3 \\
22950 \cdot 0 \\
0 \\
0 \\
806 \cdot 0\end{array}$ \\
\hline Arable & $\begin{array}{l}\text { Mx } 1 \\
\text { Mx } 2 \\
\text { Mx } 3 \\
\text { ISP } 069 \\
\text { ISP } 015 \\
\text { ISP } 236\end{array}$ & $\begin{array}{c}17 \cdot 0 \\
50 \cdot 0 \\
56 \cdot 0 \\
0 \\
0 \\
16 \cdot 0\end{array}$ & $\begin{array}{c}82 \cdot 0 \\
117 \cdot 0 \\
181 \cdot 0 \\
0 \\
0 \\
107 \cdot 0\end{array}$ & $\begin{array}{c}225 \cdot 0 \\
641 \cdot 7 \\
666 \cdot 7 \\
0 \\
0 \\
277 \cdot 0\end{array}$ & $\begin{array}{c}275 \cdot 0 \\
1283 \cdot 3 \\
1858 \cdot 3 \\
0 \\
0 \\
660 \cdot 0\end{array}$ \\
\hline Garden (1) & $\begin{array}{l}\text { Mx } 1 \\
\text { Mx } 2 \\
\text { Mx } 3 \\
\text { ISP } 069 \\
\text { ISP } 015 \\
\text { ISP } 236\end{array}$ & $\begin{array}{c}13 \cdot 0 \\
16 \cdot 0 \\
41 \cdot 0 \\
0 \\
0 \\
0\end{array}$ & $\begin{array}{c}87 \cdot 0 \\
35 \cdot 0 \\
98 \cdot 0 \\
0 \\
0 \\
0\end{array}$ & $\begin{array}{c}233 \cdot 3 \\
207 \cdot 0 \\
558 \cdot 3 \\
0 \\
0 \\
0\end{array}$ & $\begin{array}{r}1516 \cdot 7 \\
558 \cdot 3 \\
2868 \cdot 3 \\
0 \\
0 \\
0\end{array}$ \\
\hline Garden (2) & $\begin{array}{ll}\text { Mx } & 1 \\
\text { Mx } & 2 \\
\text { Mx } & 3 \\
\text { ISP } & 069 \\
\text { ISP } & 015 \\
\text { ISP } & 236\end{array}$ & $\begin{array}{l}0 \\
1 \cdot 0 \\
5 \cdot 0 \\
0 \\
0 \\
3 \cdot 0\end{array}$ & $\begin{array}{c}2 \cdot 0 \\
2 \cdot 0 \\
4 \cdot 0 \\
0 \\
0 \\
22 \cdot 0\end{array}$ & $\begin{array}{c}10 \cdot 7 \\
5 \cdot 0 \\
32 \cdot 3 \\
0 \\
0 \\
36 \cdot 3\end{array}$ & $\begin{array}{c}64 \cdot 7 \\
49 \cdot 0 \\
90 \cdot 7 \\
0 \\
0 \\
86 \cdot 7\end{array}$ \\
\hline Garden (3) & $\begin{array}{ll}M x & 1 \\
M x & 2 \\
M x & 3 \\
\text { ISP } & 069 \\
\text { ISP } & 015 \\
\text { ISP } & 236\end{array}$ & $\begin{array}{c}0 \\
5 \cdot 0 \\
37 \cdot 0 \\
0 \\
0 \\
0\end{array}$ & $\begin{array}{r}127 \cdot 0 \\
66 \cdot 0 \\
111 \cdot 0 \\
0 \\
0 \\
0\end{array}$ & $\begin{array}{c}121 \cdot 3 \\
58 \cdot 7 \\
164 \cdot 0 \\
0 \\
0 \\
0\end{array}$ & $\begin{array}{c}316 \cdot 7 \\
195 \cdot 7 \\
416 \cdot 7 \\
0 \\
0 \\
0\end{array}$ \\
\hline Garden (4) & $\begin{array}{ll}\text { Mx } & 1 \\
\text { Mx } & 2 \\
\text { Mx } & 3 \\
\text { ISP } & 069 \\
\text { ISP } & 015 \\
\text { ISP } & 236\end{array}$ & $\begin{array}{c}0 \\
0 \\
48 \cdot 0 \\
0 \\
0 \\
0\end{array}$ & $\begin{array}{l}0 \\
0 \\
3 \cdot 0 \\
0 \\
0 \\
0\end{array}$ & $\begin{array}{c}0 \\
0 \\
15 \cdot 7 \\
0 \\
0 \\
0\end{array}$ & $\begin{array}{c}0 \\
0 \\
104 \cdot 0 \\
0 \\
0 \\
0\end{array}$ \\
\hline Cultivated (1) & $\begin{array}{ll}\text { Mx } & 1 \\
\text { Mx } & 2 \\
\text { Mx } & 3 \\
\text { ISP } & 069 \\
\text { ISP } & 015 \\
\text { ISP } & 236\end{array}$ & $\begin{array}{l}0 \\
0 \\
0 \\
6 \cdot 0 \\
0 \\
0\end{array}$ & $\begin{array}{c}0 \\
0 \\
0 \\
124 \cdot 5 \\
0 \\
0\end{array}$ & $\begin{array}{c}0 \\
0 \\
0 \\
64 \cdot 7 \\
0 \\
0\end{array}$ & $\begin{array}{c}0 \\
0 \\
0 \\
104 \cdot 0 \\
0 \\
0\end{array}$ \\
\hline Cultivated (2) & $\begin{array}{ll}\text { Mx } & 1 \\
\text { Mx } & 2 \\
\text { Mx } & 3 \\
\text { ISP } & 069 \\
\text { ISP } & 015 \\
\text { ISP } & 236\end{array}$ & $\begin{array}{l}0 \\
0 \\
0 \\
0 \\
0 \\
0\end{array}$ & $\begin{array}{l}0 \\
0 \\
0 \\
0 \\
1 \cdot 0 \\
0\end{array}$ & $\begin{array}{c}0 \\
0 \\
0 \\
0 \\
17 \cdot 0 \\
0\end{array}$ & $\begin{array}{l}0 \\
0 \\
0 \\
0 \\
0 \\
0\end{array}$ \\
\hline
\end{tabular}

* For details of the Methods A, B, C and D, see Methods. 
soils and the large numbers of actinophages counted in these soils may reflect host activity. Fewer actinophages were obtained for Streptomyces sp. ISP 069, ISP 015 and ISP 236 which were type cultures not originating from the soils under study.

In order to understand the ecological significance of phages in natural soil, it is first necessary to have an efficient method for their detection and enumeration. The results of this study suggest that existing direct isolation procedures may seriously underestimate the actual numbers of actinophages in soil due to major 'losses' incurred during agitation, centrifugation, filter sterilization and the use of unsuitable eluents. The two suggested procedures, Methods $\mathrm{C}$ and $\mathrm{D}$ for chloroform-sensitive and chloroform-resistant actinophages, respectively, minimize these losses.

Method $\mathrm{C}$ is more efficient than existing direct isolation procedures tested. Although losses of up to $67 \%$ may be incurred by adsorption of phage particles to the filter, filter sterilization is probably the only available method for the isolation of chloroform-sensitive actinophages. Alternative methods for preventing growth of soil bacteria on assay plates, such as drying soil, heat, thymol, phenol, antibiotics, lysozyme, selective centrifugation and modification of the assay medium were found to be unsuitable (unpublished data).

Soil extracts may be effectively sterilized by treatment with $2 \%(\mathrm{v} / \mathrm{v})$ chloroform applied to the supernatant after centrifugation and this does not inhibit growth of the streptomycete host (Method D). This method is therefore particularly useful for actinophage enumeration in soils with a high clay content. When filtration is used most phages will be lost by adsorption of phage/colloid complexes to the filters. However, some phages are inactivated by chloroform (Eisenstark, 1967; Billing, 1969) so only the chloroform-resistant phages from the natural soil population will be enumerated. This method yielded considerably greater numbers of actinophages than have previously been reported using direct isolation procedures (Khavina, 1954; Welsch et al., 1955; Collard, 1970).

It is impossible to provide optimal conditions for the isolation of all actinophages present in a given sample, since phage-host systems differ considerably in their susceptibility to inactivation by a range of environmental conditions. However, the suggested procedures should facilitate a more realistic estimate of numbers of actinophages in the soil mass or in microsites of host activity. This will provide a basis for more detailed studies of actinophage-host interactions in soil. Hopefully the methods will also be applicable to ecological studies of the phages of other bacteria.

This work was supported by N.E.R.C. Research Grant (GR3/3672). We are grateful for helpful discussions with Dr S. B. Primrose and Dr N. Seeley, Department of Biological Sciences, University of Warwick.

\section{REFERENCES}

ADAMS, M. H. (1948). Surface inactivation of bacterial viruses and of proteins. Journal of General Physiology 31, 417-431.

ADAMS, M. H. (1959). In Bacteriophages. London: Wiley-Interscience.

BALL, D. F. (1964). Loss-on-ignition as an estimate of organic matter and organic carbon in non-calcareous soils. Journal of Soil Science 15, 84-92.

BILliNG, E. (1969). Isolation, growth and preservation of bacteriophages. Methods in Microbiology 3B, 315329.

BITTON, G. (1975). Adsorption of viruses on to surfaces in soil and water. Water Research 2, 473-484.

Bradley, S. G., ANderson, D. L. \& Jones, L. A. (1961). Phylogeny of actinomycetes as revealed by susceptibility to actinophage. Developments in Industrial Microbiology 2, 223-237.

BURGE, W. D. \& ENKIRI, N. K. (1978). Virus adsorption by five soils. Journal of Environmental Quality 7 , 73-76.
Carlson, G. F., Woodward, F. W., Wentworth, D. P. \& SPROUL, O. J. (1968). Virus inactivation on clay particles in natural waters. Journal of the Water Pollution Control Federation 40, R89-R106.

CASIDA, L. E. \& LIU, L. (1974). Arthrobacter globiformis and its bacteriophage in soil. Applied Microbiology 28, 951-959.

Collard, C. A. (1970). Comparative studies of methods of isolation of actinophage starting with their natural habitat. Comptes rendus des séances de la Société de Biologie 164, 465-468.

Crosse, J. E. \& Hingorani, M. K. (1958). A method for isolating Pseudomonas mors-prunorum phages from the soil. Nature, London 181, 60-61.

DAY, P. R. (1965). Particle Fractionation and Particlesize analysis. In 'Methods of Soil Analysis', Agronomy No. 9, Part I, pp. 545-567. Edited by C. A. Black, D. D. Evans, J. L. White, L. F. Ensminger \& F. E. Clarke. Madison, Wisconsin: American Society of Agronomy. 
DE ViCENTE, J. (1959). A study of the adsorption of bacteriophage by filters. Applied Microbiology 7 , 239-247.

DowDING, J. E. (1973). Characterisation of a bacteriophage virulent for Streptomyces coelicolor A3(2). Journal of General Microbiology 76, 163-176.

DowdinG, J. E. \& Hopwood, D. A. (1973). Temperate bacteriophages for Streptomyces coelicolor A3(2) isolated from soil. Journal of General Microbiology 78, 111.

Duboise, S. M., Moore, B. E. \& SAGik, B. P. (1976). Poliovirus survival and movement in a sandy forest soil. Applied and Environmental Microbiology 31, 536543.

EISENSTARK, A. (1967). Bacteriophage techniques. In 'Methods in Virology', vol. I, pp. 450-524. Edited by K. Maramorosch \& H. Koprowski. London \& New York: Academic Press.

Gerba, C. P., Smith, E. M. \& Melnick, J. L. (1977). Development of a quantitative method for detecting enteroviruses in estuarine sediments. Applied and Environmental Microbiology 34, 158-163.

GermidA, J. J. \& CASIDA, L. E. (1981). Isolation of Arthrobacter bacteriophage from soil. Applied and Environmental Microbiology 41, 1389-1393.

Gray, T. R. G. \& Williams, S. T. (1971). Microbial productivity in soil. In Microbes and Biological Productivity'. Edited by E. D. Hughes \& A. Rose. Cambridge: Cambridge University Press.

Hurst, C. J. \& Gerba, C. P. (1979). Development of a quantitative method for the detection of enteroviruses in soil. Applied and Environmental Microbiology 37, 626-632.

Hurst, C. J., Farrah, S. R., Gerba, C. P. \& Melnick, J. L. (1978). Development of quantitative methods for the detection of enteroviruses in sewage sludge during activation and following land disposal. $A p$ plied and Environmental Microbiology 36, 81-89.

JaKUBOWSKI, W. (1969). Adsorption of poliovirus in seawater by clay minerals and marine sediments. Bacteriological Proceedings V198.

KHAVINA, E. S. (1954). Isolation of actinophage from soils. Trudy Instituta mikrobiologii. Akademiya nauk SSSR 3, 224.

Khavina, E. S. \& Rautenstein, Y. I. (1959). Effect of $\mathrm{pH}$ of the medium on the isolation of actinophages from podzol soil. Microbiology 28, 685-691.

LandRy, E. F., Vaughn, J. M., Thomas, M. Z. \& VICALE, T. J. (1978). Efficiency of beef extract for the recovery of poliovirus from wastewater effluents. Applied and Environmental Microbiology 36, 544-548.

Newbould, F. H. S. \& Garrard, E. H. (1954). Studies on actinophage for Streptomyces scabies (Thaxt.) Waksman and Henrici. Canadian Journal of Botany 32, 386-391.

Ostle, A. G. \& Holt, J. G. (1979). Elution and inactivation of bacteriophages on soil and cationexchange resin. Applied and Environmental Microbiology 38, 59-65.

Ramia, S. \& Sattar, S. A. (1979). Second-step concentration of viruses in drinking and surface waters using polyethylene glycol hydro-extraction. Canadian Journal of Microbiology 25, 587-592.

REANNEY, D. C. (1968). An assay for Bacillus stearothermophilus using thermophilic virus. New Zealand Journal of Agricultural Research 11, 763-770.

REANNEY, D. C. \& MARSH, S. C. N. (1973). The ecology of viruses attacking Bacillus stearothermophilus in soil. Soil Biology and Biochemistry 5, 399-408.

RETINSKAYA, V. I. \& RAUTENSTEIN, Y. I. (1960). The lysogenicity of Actinomyces erythreus cultures and the isolation of their specific actinophages. Microbiology 29, 613-617.

Robinson, J. B. \& CoRke, C. T. (1959). Preliminary studies on the distribution of actinophages in soil. Canadian Journal of Microbiology 5, 479-484.

SYKES, K. I. (1977). Effects of $p H$ on actinophage. Ph.D. thesis, University of Liverpool.

SYKES, K. I. \& WILliams, S. T. (1978). Interactions of actinophage and clays. Journal of General Microbiology 108, 97-102.

SyKes, K. I., Lanning, S. \& Williams, S. T. (1981). The effect of $\mathrm{pH}$ on soil actinophage. Journal of General Microbiology 122, 271-280.

TAN, J. S. H. \& REANNEY, D. C. (1976). Interactions between bacteriophages and bacteria in soil. Soil Biology and Biochemistry 8, 145-150.

Troubworst, T., Kuyper, S., De Jong, J. C. \& PlanTINGA, A. D. (1974). Inactivation of some bacterial and animal viruses by exposure to liquid-air interfaces. Journal of General Virology 24, 155-165.

Wellington, E. M. H. \& Williams, S. T. (1978). Preservation of actinomycete inoculum in frozen glycerol. Microbios Letters 6, 151-157.

WELSCH, M., MinON, A. \& SCHONFIELD, J. K. (1955). Isolation of actinophages. Experientia 11, 24-25.

Willoughby, L. G., Smith, S. M. \& Bradshaw, R. M. (1972). Actinomycete virus in freshwater. Freshwater Biology 2, 19-26.

Winer, B. J. (1962). Statistical Principles in Experimental Design. New York \& London: McGraw-Hill.

ZACHARY, A. (1974). Isolation of bacteriophage of the marine bacterium Beneckea natriegens from coastal salt marshes. Applied Microbiology 27, 980-982. 